\title{
PENGARUH GAYA KEPEMIMPINAN DAN MOTIVASI TERHADAP KINERJA KARYAWAN PADA INDUSTRI UMKM DI WILAYAH D.I. YOGYAKARTA
}

\author{
Bambang Irjanto, (be_i@yahoo.com) \\ Herman Setiawan (setiawan.herman@gmail.com) \\ Fakultas Teknik Universitas Proklamasi 45 Yogyakarta
}

\begin{abstract}
ABSRACT. Micro, small, and medium enterprises (SMEs) have an important role in the development of Indonesia's economy. They became a great power when Indonesia faced economic crisis. In addition to contributing to the national income, SMEs also have a role in providing jobs. In the face of the free market, SMEs must be able to keep up with increasing business productivity. This will happen if the quality of employee performance is good. Quality performance or achievements of good work is often influenced by several factors, could be influenced by his friend can also be influenced by his superiors. A boss usually has a leadership style that aims to influence the performance of subordinates in the hope of achieving organizational goals. In addition to leadership style, things that can affect performance is motivation. With the motivation, employees will be encouraged to work well, so they will show good performance quality performance as well.

The objective of this study was to examine the effect of leadership style and motivation on employee performance in industrial SMEs in the Special Region of Yogyakarta (DIY). This study uses survey the population of all employees of the company are classified as micro, small, and medium in DIY. The sampling method used is sampling by convenience non-probability sampling. In this study, 100 samples were taken. Methods of data collection is done by using a questionnaire containing several questions with methods of data analysis using multiple regression.The results of this study is to accept the second hypothesis proposed in which leadership style has positive influence on employee performance in industrial SMEs in DIY. And, motivation positive influence on employee performance in industrial SMEs in DIY.
\end{abstract}

Keywords: leadership style, motivation, employee performance, SMEs

\section{PENDAHULUAN}

Usaha mikro, kecil dan menengah yang sering disebut UMKM merupakan bagian penting yang sangat mempengaruhi kekuatan perekonomian Indonesia. Mereka menyumbang sebagian besar Produk Domestik Bruto tiap tahunnya. Menteri Syarif Hasan mengatakan bahwa UMKM menyumbang 57\% PDB Indonesia tahun 2013(https://www.merdeka.com/uang/menteri-syarif-klaim-ukm-sumbang-57-persen pdb-indonesia-2013.html). Selain itu, UMKM juga berperan besar dalam menyerap tenaga kerja. Dalam menghadapi pasar global, UMKM dituntut untuk bisa bersaing dengan para kompetitornya. Mereka harus bisa meningkatkan produktivitas, efisiensi, efektifitas dan kinerjanya.

Produktivitas dan kinerja sangat berhubungan dengan sumberdaya manusia. Sumberdaya manusia ini sangat penting dalam sebuah organisasi maupun perusahaan, 
karena merekalah yang nantinya akan bekerjasama dan mengerahkan sumberdayanya demi tercapainya tujuan-tujuan organisasi. Oleh karena itu diperlukan adanya sumberdaya manusia yang berkualitas. Faktor-aktor yang dapat digunakan untuk meningkatkan kinerja diantaranya adalah gaya kepemimpinan, motivasi, dan disiplin kerja (Aditya Reza, 2010).

Suranta (2002) mengatakan bahwa gaya kepemimpinan merupakan norma perilaku yang digunakan oleh seseorang pada saat orang tersebut mencoba mempengaruhi perilaku orang lain. Di dalam UMKM gaya kepemimpinan sangatlah penting, karena berdasarkan struktur organisasinya biasanya mereka sangat berdekatan. Hal ini dikarenakan sebuah usaha kecil dan menengah biasanya baru mempunyai sedikit karyawan, sehingga hubungan antara karyawan dengan atasannya sangat dekat. Pemimpin atau atasan biasanya yang akan menentukan tujuan dari usahanya, dan karyawan biasanya hanya mengikuti instruksi dari atasannya tersebut. Oleh karena itu seorang atasan dalam usaha kecil dan menengah haruslah mempunyai gaya yang bisa mempengaruhi kinerja karyawannya menjadi optimal.

Selain dipengaruhi oleh gaya kepemimpinan, kinerja seorang karyawan juga ditentukan oleh adanya motivasi. Menurut Hakim (2006) motivasi adalah dorongan, upaya dan keinginan yang ada di dalam diri manusia yang mengaktifkan, memberi daya serta mengarahkan perilaku untuk melaksanakan tugas-tugas dengan baik dalam lingkup pekerjaannya. Oleh karena itu dengan adanya motivasi tersebut, para karyawan dapat memberikan kinerja yang optimal.

UMKM merupakan penyumbang tercapainya perekonomian yang baik di Indonesia dengan menyumbang banyak pada PDB dan dalam menyerap tenaga kerja yang banyak. Oleh karena itu, mereka membutuhkan sumber daya manusia yang berkualitas. Dalam sebuah organisasi manusia merupakan sumber daya yang sangat menentukan dalam pencapaian tujuan-tujuan yang diinginkan. Permasalahan yang dihadapi UMKM dalam mencapai tujuannya adalah pada tinggi rendahnya kinerja karyawan, sehingga diperlukan upaya-upaya yang bisa meningkatkan kinerja sumber daya manusianya. Dengan permasalahan tersebut, penelitian ini akan menitik beratkan pada faktor-faktor yang mempengaruhi kinerja karyawan. Oleh karena itu, dalam penelitian ini akan merumuskan pertanyaan penelitian sebagai berikut:

1. Apakah gaya kepemimpinan akan mempengaruhi kinerja karyawan pada industri UMKM di DIY?

2. Apakah motivasi akan mempengaruhi kinerja karyawan pada industri UMKM di DIY?

Tujuan dari penelitian ini adalah untuk memperoleh bukti empiris apakah variabel gaya kepemimpinan dan motivasi berpengaruh positif terhadap kinerja karyawan pada industri UMKM di DIY. Sedang target luaran penelitiandiharapkan bisa memberikan masukan kepada para pelaku industri UMKM dalam mengelola sumberdaya manusia (SDM) supaya bisa meningkatkan kinerja dan juga bisa mencapai tujuan-tujuan yang diharapkan.

\section{TINJAUAN PUSTAKA}

\section{A. Usaha Mikro Kecil dan Menengah (UMKM)}

Sesuai dengan Undang- Undang Nomor 20 Tahun 2008 tentang Usaha Mikro, Kecil dan Menengah (UMKM), pengertian UMKM adalah: 
a. Usaha Mikro adalah usaha produktif milik orang perorangan dan/atau badan usaha perorangan yang memenuhi kriteria Usaha Mikro sebagaimana diatur dalam UndangUndang ini. Kriteria: asset maksimal 50 juta dan omzet maksimal 300 juta

b. Usaha Kecil adalah usaha ekonomi produktif yang berdiri sendiri, yang dilakukan oleh orang perorangan atau badan usaha yang bukan merupakan anak perusahaan atau bukan cabang perusahaan yang dimiliki, dikuasai, atau menjadi bagian baik langsung maupun tidak langsung dari usaha menengah atau usaha besar yang memenuhi kriteria Usaha Kecil sebagaimana dimaksud dalam Undang-Undang ini. Kriteria: asset > 50 Juta - 500 Juta dan omzet > 300 Juta - 2,5 Miliar.

c. Usaha Menengah adalah usaha ekonomi produktif yang berdiri sendiri, yang dilakukan oleh orang perseorangan atau badan usaha yang bukan merupakan anak perusahaan atau cabang perusahaan yang dimiliki, dikuasai, atau menjadi bagian baik langsung maupun tidak langsung dengan Usaha Kecil atau usaha besar dengan jumlah kekayaan bersih atau hasil penjualan tahunan sebagaimana diatur dalam Undang-Undang ini. Kriteria: asset > 500 Juta - 10 Miliar dan omzet > 2,5 Miliar 50 Miliar.

\section{B. Kinerja karyawan}

Kinerja merupakan perilaku organisasi yang secara langsung berhubungan dengan produksi barang atau penyampaian jasa. Informasi tentang kinerja organisasi merupakan suatu hal yang sangat penting digunakan untuk mengevaluasi apakah proses kinerja yang dilakukan organisasi selama ini sudah sejalan dengan tujuan yang diharapkan atau belum. Akan tetapi dalam kenyataannya banyak organisasi yang justru kurang atau bahkan tidak jarang ada yang mempunyai informasi tentang kinerja dalam organisasinya. Kinerja sebagai hasil-hasil fungsi pekerjaan/kegiatan seseorang atau kelompok dalam suatu organisasi yang dipengaruhi oleh berbagai faktor untuk mencapai tujuan organisasi dalam periode waktu tertentu (Tika, 2006).

\section{Gaya kepemimpinan}

Terdapat lima gaya kepemimpinan yang disesuaikan dengan situasi menurut Siagian (2002), yaitu:

a. Tipe pemimpin yang otokratik. Seorang pemimpin yang otokratik ialah seorang pemimpin yang: menganggap organisasi sebagai milik pribadi, mengidentikan tujuan pribadi dengan tujuan organisasi, menganggap bahwa sebagai alat semata-mata, Tidak mau menerima kritik, saran dan pendapat, terlalu tergantung pada kekuasaan formalnya dan dalam tindakannya penggerak sering mempergunakan pendekatan yang mengandung unsur paksaan dan bersifat menghukum (puntif)

b. Tipe pemimpin yang militeristik. Perlu diperhatikan terlebih dahulu bahwa yang dimaksud seorang pemimpin tipe militeristik berbeda dengan seorang pemimpin modern. Seorang pemimpin yang bertipe militeristik ialah seorang pemimpin yang memiliki sifat-sifat: dalam menggerakkan bawahannya sistem perintah yang sering dipergunakan, dalam menggerakkan bawahannya senang bergantung pada pangkat dan jabatan. Senang kepada formalitas yang berlebih-lebihan menuntut disiplin yang tinggi dan kaku dari bawahannya.

c. Tipe pemimpin yang paternalistik. Menganggap bawahan sebagai manusia yang tidak dewasa, bersikap terlalu melindungi, arang memberikan kesempatan kepada bawahannya untuk mengambil keputusan, jarang memberikan kesempatan kepada bawahan untuk mengambil inisiatif, jarang memberikan kesempatan kepada bawahan untuk mengembangkan daya kreasi dan fantasi, Sering bersikap mau tahu. 
d. Tipe pemimpin yang kharismatik. Harus diakui bahwa untuk keadaan tentang seorang pemimpin yang demikian sangat diperlukan, akan tetapi sifatnya yang negatif mengalahkan sifatnya yang positif.

e. Tipe pemimpin yang demokratik. Pengetahuan tentang kepemimpinan telah membuktikan bahwa tipe pemimpin yang demokratislah yang paling tepat untuk organisasi modern karena: Ia senang menerima saran, pendapat dan bahkan kritikan dari bawahan.Selalu berusaha mengutamakan kerjasama (teamwork) dalam usaha mencapai tujuan, selalu berusaha menjadikan lebih sukses dari padanya, selalu berusaha mengembangkan kapasitas diri pribadinya sebagai pemimpin.

Robinss (2006) mengidentifikasi empat jenis gaya kepemimpinan yaitu:

a. Gaya kepemimpinan kharismatik. Para pengikut terpacu kemampuan kepemimpinan yang heroik atau yang luar biasa ketika mereka mengamati perilaku-perilaku tertentu pemimpin mereka. Terdapat lima karakteristik pokok pemimpin kharismatik: 1). Visi dan artikulasi. Dia memiliki visi ditunjukkan dengan sasaran ideal yang berharap masa depan lebih baik daripada status quo,dan mampu mengklarifikasi pentingnya visi yang dapat dipahami orang lain. 2). Rasio personal. Pemimpin kharismatik bersedia menempuh risiko personal tinggi, menanggung biaya besar, dan terlibat ke dalam pengorbanan diri untuk meraih visi. 3). Peka terhadap lingkungan. Mereka mampu menilai secara realistis kendala lingkungan dan sumber daya yang dibutuhkan untuk membuat perubahan. 4). Kepekaan terhadap kebutuhan pengikut. Pemimpin kharismatik perseptif (sangat pengertian) terhadap kemampuan orang lain dan responsif terhadap kebutuhan dan perasaan mereka. 5). Perilaku tidak konvensional. Pemimpin kharismatik terlibat dalam perilaku yang dianggap baru dan berlawanan dengan norma.

b. Gaya kepemimpinan transaksional. Pemimpin transaksional merupakan pemimpin yang memandu atau memotivasi para pengikut mereka menuju sasaran yang ditetapkan dengan memperjelas persyaratan peran dan tugas. Gaya kepemimpinan transaksional lebih berfokus pada hubungan pemimpin-bawahan tanpa adanya usaha untuk menciptakan perubahan bagi bawahannya. Terdapat empat karakteristik pemimpin transaksional: 1). Imbalan kontingen: kontrak pertukaran imbalan atas upaya yang dilakukan, menjanjikan imbalan atas kinerja baik, mengakui pencapaian. 2) Manajemen berdasar pengecualian (aktif): melihat dan mencari penyimpangan dari aturan dan standar, menempuh tindakan perbaikan. 3). Manajemen berdasar pengecualian (pasif): mengintervensi hanya jika standar tidak dipenuhi. 4). LaissezFaire: melepas tanggung jawab, menghindari pembuatan keputusan.

c. Gaya kepemimpinan transformasional. Pemimpin transformasional mencurahkan perhatian pada hal-hal dan kebutuhan pengembangan dari masing-masing pengikut, Pemimpin transformasional mengubah kesadaran para pengikut akan persoalanpersoalan dengan membantu mereka memandang masalah lama dengan cara-cara baru, dan mereka mampu menggairahkan, membangkitkan, dan mengilhami para pengikut untuk mengeluarkan upaya ekstra demi mencapai sasaran kelompok. Terdapat empat karakteristik pemimpin transformasional: 1). Kharisma: memberikan visi dan rasa atas misi, menanamkan kebanggaan, meraih penghormatan dan kepercayaan. 2). Inspirasi: mengkomunikasikan harapan tinggi, menggunakan simbol untuk memfokuskan pada usaha, menggambarkan maksud penting secara sederhana. 3). Stimulasi intelektual: mendorong intelegensia, rasionalitas, dan pemecahan masalah secara hati-hati. 4). Pertimbangan individual: memberikan perhatian pribadi, melayani karyawan secara pribadi, melatih dan menasehati. 
d. Gaya kepemimpinan visioner. Kemamuan menciptakan dan mengartikulasikan visi yang realistis, kredibel, dan menarik mengenai masa depan organisasi atau unit organisasi yang tengah tumbuh dan membaik dibanding saat ini. Visi ini jika diseleksi dan diimplementasikan secara tepat, mempunyai kekuatan besar sehingga bisa mengakibatkan terjadinya lompatan awal ke masa depan dengan membangkitkan keterampilan, bakat, dan sumber daya untuk mewujudkannya.

\section{Motivasi}

Motivasi merupakan faktor psikologis yang menunjukan minat individu terhadap pekerjaan, rasa puas dan ikut bertanggung jawab terhadap aktivitas atau pekerjaan yang dilakukan (Masrukhin dan Waridin, 2004). Sedangkan Hasibuan (2004) berpendapat bahwa motivasi adalah hal yang menyebabkan, menyalurkan dan mendukung perilaku manusia, supaya mau bekerja giat dan antusias mencapai hasil yang optimal. Motivasi merupakan sesuatu yang membuat bertindak atau berperilaku dalam cara-cara tertentu (Armstrong, 1994). Siagian (2002) ada enam teknik aplikasi teori motivasi, yaitu: a. Manajemen berdasarkan sasaran atau management by objectives (MBO). b. Program penghargaan karyawan. c. Program ketertiban karyawan. d. Program imbalan bervariasi. e. Rencana pemberian imbalan berdasarkan keterampilan. f. Manfaat yang fleksibel.

Menurut Rivai (2004) terdapat beberapa perilaku yang dapat memotivasi karyawan: a. Cara berinteraksi. b.Menjadi pendengar aktif. c.Penyusunan tujuan yang menantang. d. Pendekatan penyelesaian masalah dan tujuan yang berfokus pada perilaku bukan pada pribadi. e. Informasi yang menggunakan teknik penguatan.

Siagian (2002) mengemukakan bahwa dalam kehidupan berorganisasi, termasuk kehidupan berkarya dalam organisasi bisnis, aspek motivasi kerja mutlak mendapat perhatian serius dari para manajer. Karena 4 (empat) pertimbangan utama yaitu: a. Filsafat hidup manusia berkisar pada prinsip "quit pro quo", yang dalam bahasa awam dicerminkan oleh pepatah yang mengatakan "ada ubi ada talas, ada budi ada balas". b. Dinamika kebutuhan manusia sangat kompleks dan tidak hanya bersifat materi, akan tetapi juga bersifat psikologis. c.Tidak ada titik jenuh dalam pemuasan kebutuhan manusia. d. Perbedaan karakteristik individu dalam organisasi atau perusahaan, mengakibatkan tidak adanya satupun teknik motivasi yang sama efektifnya untuk semua orang dalam organisasi juga untuk seseorang pada waktu dan kondisi yang berbedabeda.

Berdasar tinjauan pustaka di atas maka dapat dibuat kerangka pikir penelitian sebagai berikut: Kinerja adalah hasil pencapaian kinerja karyawan yang dibandingkan dengan standar-standar yang sudah ditetapkan yang berhubungan dengan tercapainya tujuan perusahaan. Gaya kepemimpinan dalam penelitian ini adalah gaya pemimpin yang visioner, kharismatik, dan demokratis, yang bisa mempengaruhi karyawannya untuk melaksanakan tugas dengan baik, memberikan contoh yang baik terhadap karyawannya, dapat menerima kritikan, dan bisa membuat karyawannya merasa diperhatikan, sehingga akan meningkatkan kinerja karyawan. Motivasi juga merupakan hal yang menyebabkan, menyalurkan, dan mendukung perilaku manusia supaya mau bekerja giat dan antusias mencapai hasil yang optimal sehingga meningkatkan kinerja karyawan. Dengan demikian dapat disimpulkan bahwa secara teori gaya kepemimpinan dan motivasi akan dapat meningkatkan kinerja karyawan. Kerangka pikir tersebut dapat digambarkan sebagai berikut: 


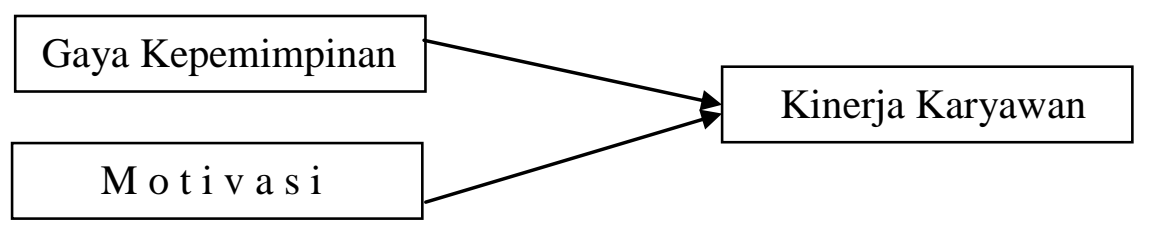

Gambar 1

Kerangka Pikir Penelitian

Berkenaan dengan kerangka pikir tersebut maka hipotesis yang dikemukakan di sini adalah:

1. Gaya kepemimpinan berpengaruh positif terhadap kinerja karyawan industri UMKM di DIY.

2. Motivasi berpengaruh positif terhadap kinerja karyawan industri UMKM di DIY.

\section{METODE PENELITIAN}

Penelitian ini dilakukan pada Industri UMKM di Wilayah DI Yogyakarta. Sampel dalam penelitian ini adalah karyawan pada industri UMKM yang berada di wilayah DIY. Pengambilan sampel dalam penelitian ini menggunakan teknik convenience nonprobability sampling yang artinya mengambil sampel menurut kemudahan untuk mengakses sampel tersebut dan anggota populasi tersebut tidak mempunyai peluang yang sama untuk terpilih menjadi sampel.

Variabel dalam penelitian ini terdiri dari variabel independen (variabel yang mempengaruhi dan variabel dependen (varabel yang dipengaruhi). Variabel independen penelitian ini adalah gaya kepemimpinan dan motivasi. Sedangkan variabel dependennya adalah kinerja karyawan.

1. Gaya kepemimpinan. Variabel gaya kepemimpinan dalam penelitian ini mengacu pada penelitian yang dilakukan oleh Aditya Reza (2010), yang dalam kuesionernya memberikan pertanyan-pertanyaan sebagai berikut:

a. Pemimpin anda sering menekankan pentingnya tugas dan meminta anda melaksanakan tugas dengan sebaik-baiknya.

b. Pemimpin anda mempengaruhi cara pandang anda untuk menyelesaikan masalah pekerjaan.

c. Pemimpin anda mengkomunikasikan tujuan dan memberikan kesempatan bagi karyawan untuk mencapai sesuatu dengan cara mereka sendiri.

d. Pemimpin anda menghargai dan memuji karyawan yang kinerjanya bagus.

Jadi yang dimaksud dengan gaya kepemimpinan dalam penelitian ini adalah gaya pemimpin yang visioner, kharismatik, dan demokratis, yang bisa mempengaruhi karyawannya untuk melaksanakan tugas dengan baik, memberikan contoh yang baik terhadap karyawannya, dapat menerima kritikan, dan bisa membuat karyawannya merasa diperhatikan.

2. Motivasi.Untuk variabel motivasi, peneliti juga mengacu pada pertanyaan-pertanyaan yang ada pada kuesioner yang dikembangkan oleh Aditya Reza (2010) sebagai Saya mendapatkan kebutuhan yang layak.

a. Saya merasa aman dalam melakukan pekerjaan.

b. Saya mempunyai hubungan yang erat dengan semua karyawan. 
c. Saya sering dan ingin selalu mendapat penghargaan atas pekerjaan yang saya lakukan.

d. Saya senang melaksanakan tugas yang menantang.

Jadi, dalam penelitian ini yang dimaksud dengan motivasi adalah sesuai dengan motivasi yang didefinisikan oleh Rivai (2004), yaitu serangkaian sikap dan nilai-nilai yang mempengaruhi individu untuk mencapai hal yang spesifik sesuai dengan tujuan individu. Motivasi juga merupakan hal yang menyebabkan, menyalurkan, dan mendukung perilaku manusia supaya mau bekerja giat dan antusias mencapai hasil yang optimal (Hasibuan, 2004).

3. Kinerja karyawan. Definisi kinerja karyawan dalam penelitian ini mengacu pada pengertian yang dipaparkan oleh Guritno dan Waridin (2005), yaitu kinerja merupakan perbandingan hasil kerja yang dicapai oleh karyawan dengan standar yang sudah ditentukan. Selain itu juga mengacu pada devinisi yang dipaparkan oleh Hakim (2006) yaitu kinerja adalah hasil kerja yang dicapai oleh individu yang disesuaikan dengan peran atau tugas individu tersebut dalam suatu perusahaan pada periode waktu tertentu yang dihubungkan dengan suatu ukuran nilai atau standar tertentu dari perusahaan tempat individu tersebut bekerja. Jadi, dalam penelitian ini yang dimaksud dengan kinerja adalah hasil pencapaian kinerja karyawan yang dibandingkan dengan standar-standar yang sudah ditetapkan yang berhubungan dengan tercapainya tujuan perusahaan.

\section{METODE PENGUMPULAN DATA}

Data dalam penelitian ini diperoleh dengan cara melakukan survei yang memberikan pertanyaan - pertanyaan yang tertuang dalam kuesioner. Kuesioner dalam penelitian ini menggunakan skala Likert dengan lima pilihan jawaban, yaitu Sangat Tidak Setuju (STS) diberi nilai 1, Tidak Setuju (TS) diberi nilai 2, Netral (N) diberi nilai 3, Setuju (S) diberi nilai 4, dan Sangat Setuju (SS) diberi nilai 5. Pengujian Instrumen Penelitian (Kuesioner) meliputi uji:

a. Validitas. Validitas menunjukkan sejauh mana ketepatan dan kecermatan suatu alat ukur dalam melakukan fungsinya. Suatu tes atau instrumen pengukur dikatakan memiliki validitas yang tinggi apabila alat tersebut bisa menjalankan fungsinya sebagai alat ukur atau dapat memberikan hasil ukur yang sesuai dengan tujuan dari pengukuran tersebut (Sekaran, 2000). Untuk mengetahui kevalidannya penelitian ini menggunakan Uji Pearson Product Moment. Jika nilai korelasi dari skor tiap butir pertanyaan dengan skor total jawaban lebih besar atau sama dengan nilai $r$ tabel (Tabel Product Moment Correlation dengan $\alpha=0,05$ ), maka pertanyaan tersebut valid. Hasil uji validitas untuk semua item pertanyaan variabel gaya kepemimpinan (A1-A6), motivasi (B1-B8) dan kinerja karyawan (C1-C7), diperoleh nilai korelasi Pearson (r) semuanya di atas nilai kritis $(0,1541)$. Dengan demikian semua item pertanyaan dinyatakan valid.

b. Reliabilitas. Reliabilitas menunjukkan sejauh mana pengukuran dapat memberikan hasil yang relatif tidak berbeda bila dilakukan pengukuran kembali terhadap subjek yang sama (Sekaran, 2000). Reliabilitas berkaitan dengan akurasi, konsistensi, dan stabilitas alat ukur. Instrumen dapat dikatakan reliabel jika dapat mengukur dengan stabil dan konsisten. Untuk menguji reliabilitas instrument dalam penelitian ini menggunakan Cronbach's coefficient alpha. Menurut Hair et al., (2010) bahwa rule 
of thumbs dari nilai alpha sebesar 0,7 namun nilai 0,6 masih dapat diterima. Uji reliabilitas dengan menghitung alpha cronbach diperoleh hasil alpha untuk variabel gaya kepemimpinan $(0,670)$, motivasi $(0,755)$ dan kinerja karyawan $(0,674)$. Semua nilai alpha di atas 0,6 sehingga semua variabel dinyatakan reliabel.

\section{METODE ANALISIS DATA}

Analisis data yang dilakukan meliputi uji asumsi klasik, uji model penelitian dan uji hipotesis sebagai berikut:

\section{Uji Asumsi Klasik.}

Dalam model regresi terdapat beberapa asumsi yang harus dipenuhi, asumsi tersebut antara lain 1) data distribusi normal, 2) tidak terdapat autokorelasi pada residual dari setiap variabel penjelas, 3) homokedastisitas (varians dari residual adalah konstan), 4) tidak terdapat multikolinearitas. Untuk memenuhi asumsi - asumsi tersebut dilakukan uji - uji yang dilakukan dengan menggunakan SPSS for Windows sebagai berikut:

a. Uji Normalitas. Uji statistik normalitas yang digunakan adalah uji nonparametrik Kolmogorov Smirnov juga dapat digunakan untuk menguji normalitas residual. Apabila uji tersebut menunjukkan angka yang signifikan, berarti data residual terdistribusi tidak normal (Ghozali, 2007).

b. Uji Autokorelasi. Gujarati (1995) menyatakan bahwa autokorelasi muncul ketika terdapat korelasi di antara beberapa observasi yang berurutan dalam waktu atau ruang, autokorelasi juga muncul karena observasi yang berurutan sepanjang waktu berkaitan satu sama lain, selain itu autokorelasi menyebabkan koefisien regresi tidak efisien meskipun tetap linear dan tidak bias.

c. Uji Heteroskedastisitas. Heterokedastisitas muncul apabila varians dari residual tidak memiliki nilai konstan (Gujarati, 1995). Uji yang digunakan adalah Uji Glejser. Sedangkan kriteria yang digunakan adalah jika nilai Sig. lebih kecil atau sama dengan 0,05 menunjukkan terjadi heteroskadastisitas, begitu pula sebaliknya.

d. Uji Multikolinearitas. Multikolinearitas merujuk pada adanya hubungan linear sempurna di antara beberapa variabel penjelas dalam suatu model regresi (Ragnar Frisch dalam Gujarati,1995). Uji yang digunakan adalah Variance Invlation Factor (VIF). Sebagai rule of thumb adalah jika VIF melebihi 10 berarti tedapat multikolinearitas.

2. Uji Model penelitian. Pengukuran goodness of fit digunakan untuk melihat ketepatan suatu model penelitian yang digunakan. Setidaknya pengukuran tersebut dengan melakukan uji statistik t, uji statistik F, dan uji $\mathrm{R}^{2}$.

a. Uji Statistik F. Untuk memperlihatkan linearitas garis regresi digunakan uji F. Uji ini merupakan persyaratan untuk menentukan apakah garis regresi dapat digunakan untuk menganalisis data. Dengan bantuan SPSS for Windows, persamaan garis regresi akan linear jika nilai Sig. kurang dari 0,05, dan persamaan garis akan tidak linear jika nilai Sig. lebih dari atau sama dengan 0,05 .

b. Uji $R^{2}$. Untuk mengukur seberapa jauh variabel independen mempengaruhi variabel dependen uji yang digunakan adalah uji $R^{2}$. Nilai $R^{2}$ berada di antara 0 dan 1 . Jika $\mathrm{R}^{2}$ mendekati 1 berarti variabel independen mampu menjelaskan dengan baik variabel dependennya. Akan tetapi, bila $\mathrm{R}^{2}$ mendekati 0 ini berarti variabel independen mempunyai kemempuan terbatas dalam menjelaskan 
variabel dependennya. Namun di sisi lain nilai $\mathrm{R}^{2}$ mempunyai kelemahan. Kelemahan tersebut adalah $\mathrm{R}^{2}$ bias terhadap jumlah variabel independen yang dimasukkan ke dalam model penelitian. Oleh karena itu harus menggunakan nilai Adjusted $\mathrm{R}^{2}$.

3. Uji Hipotesis. Hipotesis - hipotesis dalam penelitian ini akan diuji menggunakan uji statistik t. Uji ini akan menunjukkan pengaruh suatu variabel independen terhadap variabel dependennya. Dengan menggunakan SPSS for windows, apabila nilai Sig. kurang dari 0,05 maka variabel independen tersebut berpengaruh terhadap variabel dependennya, begitu pula sebaliknya.

\section{HASIL PENELITIAN DAN ANALISIS DATA}

1. Gambaran Umum Responden

Penelitian dilakukan dengan menyebarkan kuesioner kepada sampel yang memenuhi kriteria penelitian, yaitu para karyawan yang bekerja di industri UMKM yang berada di sekitar wilayah Daerah Istimewa Yogyakarta. Pengumpulan data dilakukan selama tiga bulan, yaitu pertengahan bulan Juni sampai pertengahan bulan Agustus 2015. Kuesioner penelitian sebagian dikirim melalui email ke beberapa karyawan di industri umkm DIY dan sebagian diberikan secara langsung oleh peneliti di tempat mereka bekerja. Kuesioner yang diemail sebanyak 75 eksemplar, dan yang diberikan secara langsung sebanyak 70 eksemplar. Keseluruhan kuesioner yang terkumpul adalah sebanyak 135 eksemplar, dan yang dapat diolah sebanyak 115 .

2. Uji Asumsi Klasik

a. Uji Normalitas. Uji normalitas dilakukan untuk melihat bahwa suatu data terdistribusi normal atau tidak. Ghozali (2007) uji statistik non-parametrik Kolmogorov Smirnov juga dapat digunakan untuk menguji normalitas residual. Apabila uji tersebut menunjukkan angka yang signifikan, berarti data residual terdistribusi tidak normal. Hasil pengujian Kolmogorov Smirnov secara ringkas dapat dilihat pada tabel 4.8 berikut:

Tabel 4.1.

Hasil Uji Normalitas

\begin{tabular}{|c|c|c|c|c|}
\hline Variabel & $\begin{array}{c}\text { Kolmogorof- } \\
\text { Smirnov }\end{array}$ & Nilai Sig & Sig & Status \\
\hline $\begin{array}{c}\text { Unstandardized } \\
\text { residual }\end{array}$ & 1,349 & 0,058 & $\mathrm{P}>0,05$ & Normal \\
\hline
\end{tabular}

Sumber: Data Primer Diolah 2015

Dari hasil perhitungan uji Kolmogorov-Smirnov, dapat diketahui bahwa nilai unstandardized residual adalah 0,058 , lebih besar dari 0,05 ( $\mathrm{p}>0,05)$, sehingga keseluruhan data tersebut dinyatakan terdistribusi secara normal atau memiliki sebaran data yang normal.

b. Uji Autokorelasi. Autokorelasi timbul apabila terdapat korelasi antara variabel pengganggu (disturbance) pada periode $\mathrm{t}$ dengan disturbance pada periode sebelumnya (periode t-1). Uji autokorelasi dapat dilakukan dengan menghitung nilai dari uji statistik Durbin-Watson (D-W). Kriteria yang harus dipenuhi adalah sebagai berikut ( Trihendradi, 2007): 
- $1,65<$ DW $<2,35$

- $1,21<$ DW $<1,65$ atau $2,35<$ DW $<2.79$

- $\mathrm{DW}<1,21$ atau DW $>2,79$

tidak terjadi autokorelasi

tidak dapat disimpulkan

terjadi autokorelasi

Dari hasil uji autokorelasi, nilai Durbin-Watsonnya sebesar 2,129. Nilai ini terletak antara 1,65 $<\mathrm{DW}<2,35$. Oleh karena itu, dapat disimpulkan bahwa pada model penelitian ini tidak terjadi autokorelasi.

\section{c. Uji Heteroskedastisitas}

Untuk menguji heteroskedastisiitas dilakukan dengan Uji Glejser. Masalah heterokedastisitas akan terjadi bila masing-masing variabel independen mempunyai nilai Sig. lebih kecil dari alpha 0,01 (Ghozali, 2009).

Tabel 4.2

Hasil Uji Heteroskedastisitas

\begin{tabular}{|c|c|}
\hline Variabel & Signifikansi \\
\hline Gaya Kepemimpinan & 0,084 \\
\hline Motivasi & 0,240 \\
\hline Kinerja Karyawan & 0,821 \\
\hline
\end{tabular}

Sumber: Data Primer Diolah 2015

Dari hasil yang ada pada tabel di atas dapat dianalisis bahwa semua variabel yang digunakan dalam penelitian ini tidak signifikan, nilai Sig. dari masing-masing variabel independen lebih besar dari nilai alpha 0,01 , sehingga penelitian ini tidak terjadi gejala heteroskedastisitas.

\section{d. Uji Multikolinearitas}

Uji multikolinearitas ini dimaksudkan untuk mengetahui apakah terdapat inter korelasi yang sempurna diantara beberapa variabel bebas yang digunakan dalam model. Uji yang digunakan adalah Variance Invlation Factor (VIF). Sebagai rule of thumb adalah jika VIF melebihi 10 berarti tedapat multikolinearitas.

Tabel 4.3. berikut ini memperlihatkan bahwa tolerance value keempat variabel independen adalah lebih dari 0,1, dan Variance Inflation Factor (VIF) dari masingmasing variabel independen kurang dari 10. Jadi dapat ditarik kesimpulan bahwa setiap variabel dalam penelitian ini tidak mengandung multikolinearitas.

Tabel 4.3

Hasil Uji Multikolinearitas

\begin{tabular}{|c|c|c|}
\hline Variabel & Tolerance & VIF \\
\hline Kualitas Sistem Perpajakan & 0,991 & 1,009 \\
\hline Audit (Pemeriksaan) Pajak & 0,991 & 1,009 \\
\hline
\end{tabular}

Sumber: Data Primer Diolah 2015

\section{e. Pengujian Goodness of Fit Model Penelitian}

Model persamaan yang digunakan dalam penelitian ini adalah linear. Hal ini dapat dibuktikan dengan melihat nilai Sig pada hasil uji F tabel ANOVA ${ }^{\mathrm{b}}$. Nilai Sig yang dihasilkan adalah 0,004, lebih kecil dari alpha 0,050.

Analisis berikutnya adalah menentukan seberapa besar kontribusi variabelvariabel independen terhadap variabel dependen. Hal tersebut dapat dilakukan dengan melihat nilai $R^{2}$ pada Tabel Summary ${ }^{\mathrm{b}}$. Dari tabel tersebut terlihat bahwa nilai $R^{2}$ menunjukkan angka 0,095 . Hal ini berarti variabel gaya kepemimpinan dan motivasi 
baru mampu menjelaskan variabel dependen (kinerja karyawan) sebesar 9,5\%, sedangkan sisanya $90,5 \%$ dipengaruhi oleh variabel lain yang tidak dijelaskan dalam model penelitian ini.

f. Uji Hipotesis. Dengan menggunakan SPSS for windows diperoleh hasil sebagai berikut:

Tabel 4.4

Hasil Uji - $\mathrm{t}$

\begin{tabular}{|l|c|c|c|c|}
\hline Variabel & $\begin{array}{l}\text { Unstandardized } \\
\text { Coefficient Beta }\end{array}$ & t-hitung & t-tabel & Signifikansi \\
\hline Konstanta & 8,120 & 6,151 & & 0,213 \\
\hline Gaya Kepemimpinan & 0,191 & 2,280 & 0,1541 & 0,024 \\
\hline Motivasi & 0,157 & 2,032 & 0,1541 & 0.045 \\
\hline
\end{tabular}

Sumber: Data Primer Diolah 2015

Hasil uji t di atas menunjukkan bahwa variabel gaya kepemimpinanmemiliki nilai nilai $\mathrm{p}=0,024$.Dikarenakan $\mathrm{p}<0,05$, maka hipotesis null berhasil ditolak. Artinya hipotesis pertama terdukung. Semakin bagus gaya kepemimpinannya maka kinerja karyawannya semakin baik.

Hasil uji t untuk variabel motivasi pada tabel 4.4 di atas, memperlihatkan bahwa variabel ini nilai $\mathrm{p}=0,045$, dengan $\mathrm{p}<0,05$, maka hipotesis null berhasil ditolak. Artinya hipotesis kedua terdukung. Semakin besar motivasi yang diberikan oleh karyawan, maka kinerja karyawan akan semakin baik.

\section{KESIMPULAN DAN SARAN}

1. Kesimpulan

Kesimpulan dalam penelitian ini adalah:

a. Gaya kepemimpinan mempengaruhi kinerja karyawan pada industri UMKM di DIY.

b. Motivasi mempengaruhi kinerja karyawan pada industri UMKM di DIY.

2. Keterbatasan Penelitian

Penelitian ini mempunyai keterbatasan-keterbatasan sebagai berikut:

a. Metode survei dalam penelitian ini dilakukan hanya dengan mengirim email kuesioner saja, jadi kesimpulan yang dapat ditarik hanyalah sebatas pertanyaanpertanyaan yang terdapat pada kuesioner tersebut.

b. Variabel yang digunkan baru sebatas dua variabel saja, yaitu gaya kepemimpinan dan motivasi.

3. Saran

a. Menambah metode pengumpulan data dengan melakukan wawancara langsung kepada responden.

b. Menambah variabel-variabel penelitian yang dapat mempengaruhi kinerja karyawan selain gaya kepemimpinan dan motivasi. 


\section{DAFTAR PUSTAKA}

Aditya Reza, Regina: 2010, "Pengaruh Gaya Kepemimpinan, Motivasi, dan Disiplin Kerja Terhadap Kinerja Karyawan PT Sinar Sentosa Perkasa Banjarnegara". Semarang: Skripsi Fakultas Ekonomi Universitas Diponegoro.

Amstrong, Michael. 1994. Manajemen Sumber Daya Manusia: A Handbook of Human Resource Management. PT Elex Mediakomputindo. Jakarta.

Ghozali, Imam. 2007. Aplikasi Analisis Multivariate dengan Program SPSS. Semarang: Badan Penerbit Universitas Diponegoro.

Gujarati, D. N., 1995. Basic Econometrics Third Edition. Singapore: Mc. Graw Hill.

Guritno, B., dan Waridin. 2005. Pengaruh Persepsi Karyawan Mengenai Perilaku Kepemimpinan, Kepuasan Kerja dan Motivasi Terhadap Kinerja. JBRI. Vol 1. No. 1. Hal: 63-74

Hair. Jr, Jf. Black W. C, Babin B. J., Andersen R. E., and Tatham R, L.,(2010). “Data analysis Multivariate". 8th Edition. Person Education. Inc. New Jersey.

Hakim, Abdul. 2006. Analisis Pengaruh Motivasi, Komitment Organisasi, Dan Iklim Organisasi Terhadap Kinerja Pegawai Pada Dinas Perhubungan dan Telekomunikasi Provinsi Jawa Tengah. JRBI. Vol 2. Nomor 2.

Hasibuan, S.P. Malayu. 2004. Manajemen Sumber Daya Manusia. Cetakan ke Tujuh, Edisi revisi, PT. Bumi Aksara. Jakarta.

http://www.merdeka.com/uang/menteri-syarif-klaim-ukm-sumbang-57-persen-pdbindonesia-2013.html.

Masrukhin dan Waridin. 2004. Pengaruh Motivasi Kerja, Kepuasan Kerja, Budaya Organisasi, Dan Kepemimpinan Terhadap Kinerja Pegawai. EKOBIS. Vol 7. No. 2. Hal: 197-209.

Republik Indonesia, Undang-Undang Nomor 20 Tahun 2008 Tentang Usaha Mikro, Kecil, dan Menengah (UMKM).

Rivai, Veithzal. 2004. Manajemen Sumber Daya manusia Untuk Perusahaan PT Rajagrafindo Persada. Jakarta.

Robbins, S.P. 2006. Perilaku Organisasi. Edisi kesepuluh. Jakarta: PT Indeks Kelompok Gramedia.

Sekaran, Uma. 2000. Research Methods for Business Third Edition. USA: John Wiley $\&$ Sons, Inc.

Siagian, S.P. 2002. Kiat Meningkatkan Produktivitas Kerja. PT Rineka Cipta Jakarta.

Suranta, Sri. 2002. Dampak Motivasi Karyawan Pada Hubungan Antara Gaya Kepemimpinan Dengan Kinerja Karyawan Perusahaan Bisnis. Empirika. Vol 15. Nomor 2.

Tika, P. 2006. Budaya Organisasi Dan Peningkatan Kinerja Perusahaan. PT Bumi Aksara. Jakarta. 